\title{
The Mobility of Iconographers and their Quest for Social Status Art and Signatures of Transylvanian Pre-Modern Greek-Orthodox Iconographers
}

\author{
RALUCA PRELIPCEANU
}

The change in the status of Orthodox iconographers from Transylvania brought forward a change in their art during the eighteenth and early nineteenth centuries. During this period the condition of Orthodox painters changes from that of mere craftsmen to artists. Based on the work of several Transylvanian painters active during the eighteenth and early nineteenth centuries, an analysis of the signatures of the artists, visitation records and contracts between the artists and the patrons of the church, this article wishes to explore the changes in the status of these individuals who evolved from craftsmen to artists during their lives.

Keywords: iconographic representations, signatures, commissioners, church authorities, iconographers, status, upward social mobility

\section{Introduction}

Beginning in the mid-eighteenth century and continuing into the nineteenth century, Orthodox painters lived and worked in an environment that was undergoing rapid transformation due to the integration of Transylvania into the Habsburg empire at the end of the seventeenth century and also to the new Orthodox hierarchical jurisdiction exercised by the Metropolitanate of Karlowitz from 1761 onwards. Despite the firm steps towards modernity taken by society, ecclesiastical art did not become an obsolete genre and many individuals trained in monastic establishments or the workshops of various iconographers continued to receive numerous and prestigious commissions from both ecclesiastical and secular patrons. According to Marius Porumb, the eighteenth century witnessed an explosion of Romanian art with more than three hundred painters active in Transylvania ${ }^{1}$. However,

Raluca Prelipceanu, member of the International Society for Cultural History, Aleea Lunca Siretului nr. 6, Bl. A46, Sc. F, Ap. 82, 062037 Bucharest, Romania, raluca.prelipceanu@gmail.com. The author is grateful for financial support from Babeș Bolyai University for this research.

${ }^{1}$ Marius Porumb, Un veac de pictură românească din Transilvania, secolulXVIII (A Century of Romanian Painting in Transylvania: the XVIIIth century), (București: Meridiane, 2003), 5. 
due to the changes in society, one is led to inquire whether the status of these iconographers changed, forcing them to evolve from craftsmen to artists. In an attempt to answer this question, this study aims to explore the development of the status of these individuals, the Orthodox iconographers of Transylvania in the changing environment of the eighteenth and nineteenth centuries. To unravel this complicated issue, the study will look at the images produced by these painters and the specific compositional types they chose, trying to assess whether these were stimulated by their personal artistic preferences and interests or by the requirements of the donors. The other marker of upward social mobility is self-perception often reflected by the signature of the painter and the way he chose to represent himself.

This investigation is both timely and relevant as eighteenth-century religious painting from Transylvania was slow to draw scholarly attention. Barely mentioned by Ștefan Meteș ${ }^{2}$ and Coriolan Petreanu ${ }^{3}$ at the beginning of the twentieth century, practically disparaged by I.D. Ștefănescu who questioned their value because of the Western influences they harboured in their work and disregarded by Vasile Drăguț and Virgil Vătășianu as they mostly focused on medieval art, these works enjoyed due attention only in the writings of Marius Porumb, ${ }^{4}$ one of Virgil Vătășianu's disciples who dedicated a book to the artistic milieu of the eighteenth century. Since its publication, several painters have benefited from increased scholarly attention from both historians and art historians. ${ }^{5}$

Taking into account that this investigation will deal with two major issues, the changes in the images produced by eighteenth-century iconographers and the way these individuals perceived their work and status this study will proceed by way of a two-tiered approach to the subject matter addressing each question individually.

\footnotetext{
2 Ștefan Meteș, "Zugravii bisericilor române" (The Painters of the Romanian Churches), Anuarul Comisiunii Monumentelor Istorice, secția pentru Transilvania 1926-1928 (Cluj Napoca: Tipografia Progresul, 1929).

${ }^{3}$ Coriolan Petreanu, Bisericile de lemn ale romanilor ardeleni (The Wooden Churches of Romanians from Transylvania), (Sibiu: Tiparul Kraftt \& Drotleff, 1934).

${ }^{4}$ Porumb, Un veac.

${ }^{5}$ Ana Dumitran, Elena Daniela Cucui, Elena Mihu and Saveta-Florica Pop, Iacov Zugravul (Iacov the Painter), (Alba Iulia: Altip, 2010); idem, Stan Zugravul (Stan the Painter) (Alba Iulia: Altip, 2011); Vasile Mureșan and Marcel Naste, Toader Popovici Zugravul (Toader Popovici the Painter), (Târgu Mureș: Vatra Veche, 2015); Dumitran, "Un zugrav de elită: Grigore Ranite” (An Exquisite Painter: Grigore Ranite), Annales Universitatis Apulensis. Series Historica 14, no. 1 (2010), 83-98; Dumitran, "Pictorul Simion Silaghi-Sălăgeanu. În căutarea identității” (Painter Simion Silaghi Sălăgeanu. In search of an Identity), Annales Universitatis Apulensis. Series Historica 16, no. 1 (2012): 189-228; Silvia Marin Barutcieff, "Un pictor transilvănean pierdut...? Ursu Broină” (A Forgotten Transylvanian Painter...? Ursu Broină), Apulum 50 (2013), 361-78; Horia Medeleanu, "The Life of an eighteenth-century painter: Stefan Tenetchi," Revue des études sud-est européennes 21, no. 2 (1983): 125-45.
} 


\section{The Social Origins of the Painters}

At the beginning of the eighteenth century when Transylvania came under Habsburg rule, Orthodox painters from Transylvania were regarded as mere artisans and not as artists. The same state of affairs was observed in the neighbouring land of Ruthenia where some of the painters were also involved in other trades as they could not earn their living only by painting. A writer from Ostroh claimed in 1588 that "before, there were excellent, pious painters of icons, but now icon painting was dominated by saddlers, bridlemakers, and other clowns."

Unlike the Ruthenian neighbouring painters, whom we know used to come from the monastic world, we do not exactly know the social origin of Transylvanian painters. According to Ștefan Meteș at the beginning of the eighteenth century, some of the painters came from monastic orders, like Monk Gheorghe and Hieromonk Iosif.? However, during this century we notice some changes in the social origin of painters, as most of them were lay painters or clerics, like Priest Gheorghe Tobias from Abrud or Priest Nicolae of Feisa. They did not generally come from poor families. For example, the famous painters Iacov and Stan of Răşinari were the sons of Priest Radu Man. Marius Porumb even takes into account the possibility that a painter like Simion Silaghi might have come from the ranks of the petty gentry. ${ }^{8}$

In general, we do notice the existence of dynasties of painters, the craft being handed down from father to son. It is the case of the painter Iacov from Rășinari for example, whose sons Gheorghe and Nicolae were also painters, or that of Simion Silaghi who handed down his craft not only to his three sons: Gavriil, Simion and Partenie but also to his grandson Isidor. The same is true for the family of Toader Ciungar, whose sons Iacov and Nicolae were also painters. The skill was thus passed on from father to son, from generation to generation following an initiation ritual.

Several painting schools developed during this period, but no guild is recorded. Only 'the painters on paper' were apparently organized in a guild in Gherla.

At the level of the painting schools, one of the most important was that of Feisa established by Iacov of Rășinari ${ }^{9}$ when he moved there in 1762. His sons, Nicolae and Gheorghe were two of its illustrious repre-

${ }^{6}$ Lilyia Berezhnaya and John Paul Himka, The World To Come. Ukrainian Images of the Last Judgement (Cambridge: Harvard University Press, 2015), XV.

${ }^{7}$ Meteș, Zugravii, 116.

${ }^{8}$ Porumb, Un veac, 20.

${ }^{9}$ Dumitran, Cucui, Mihu, Pop, Iacov Zugravul. 
sentatives, as was Toader Popovici. The family of Iacov had close links with the famous Wallachian painter Grigore Ranite. ${ }^{10}$ Both Stan and Iacov had been his apprentices. Later, Stan opened his own workshop in Orăștie. These kinds of relations account for well-established links between the southern part of Transylvania and Wallachia. Thus, Transylvanian painters became acquainted with the Byzantine and post-Byzantine schools of painting in Wallachia.

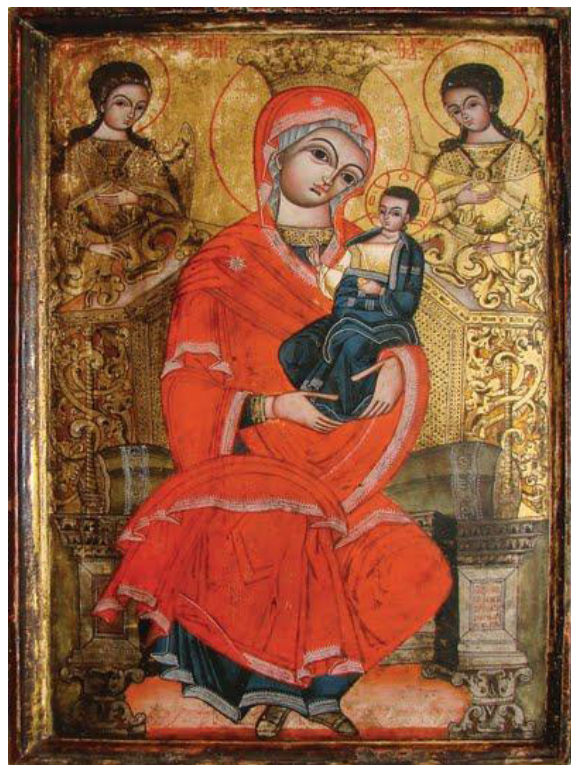

Fig. 1: The Holy Mother of God, Iacov Zugravul, 1746.

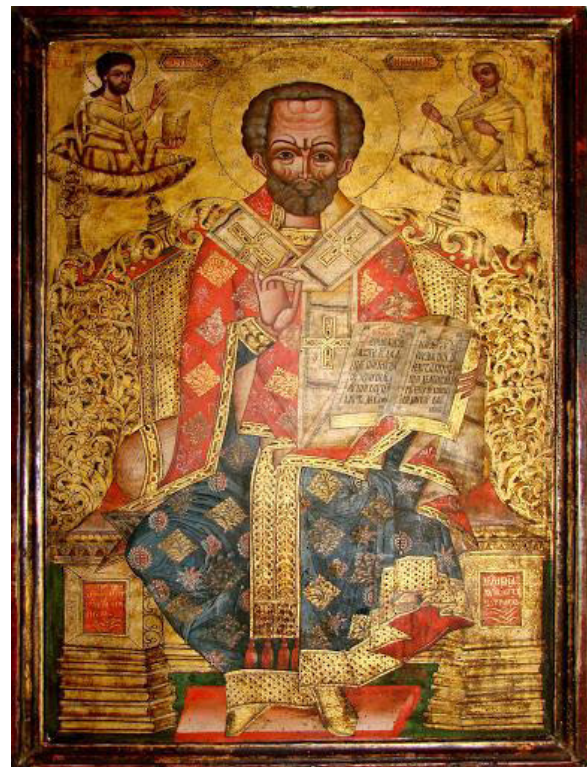

Fig. 2: St. Nicholas, Iacov Zugravul, 1745.

Grigore Ranite ${ }^{11}$ was one of the best-known representatives of the neo-Byzantine style in Wallachia developed under the reign of the MartyrPrince Constantin Brâncoveanu (1688-1714). He painted many churches in Wallachia, such as the Tismana Monastery, Crasna Skete, Sărăcinești Monastery, and the Râmnic Bishopric Chapel. His activity in Transylvania encompassed the Black Church of Brașov (1733-1734), St. Parascheva Church of Rășinari (around 1758) and the Greek Catholic Bishopric Cathedral of Blaj (1736). He introduced several eschatological images in his iconographic programmes and generally, the churches he painted have exonarthex or external decorations involving apocalyptic images.

\footnotetext{
${ }^{10}$ Ibidem, 1.

${ }^{11}$ Dumitran, "Un zugrav de elită: Grigore Ranite”.
} 

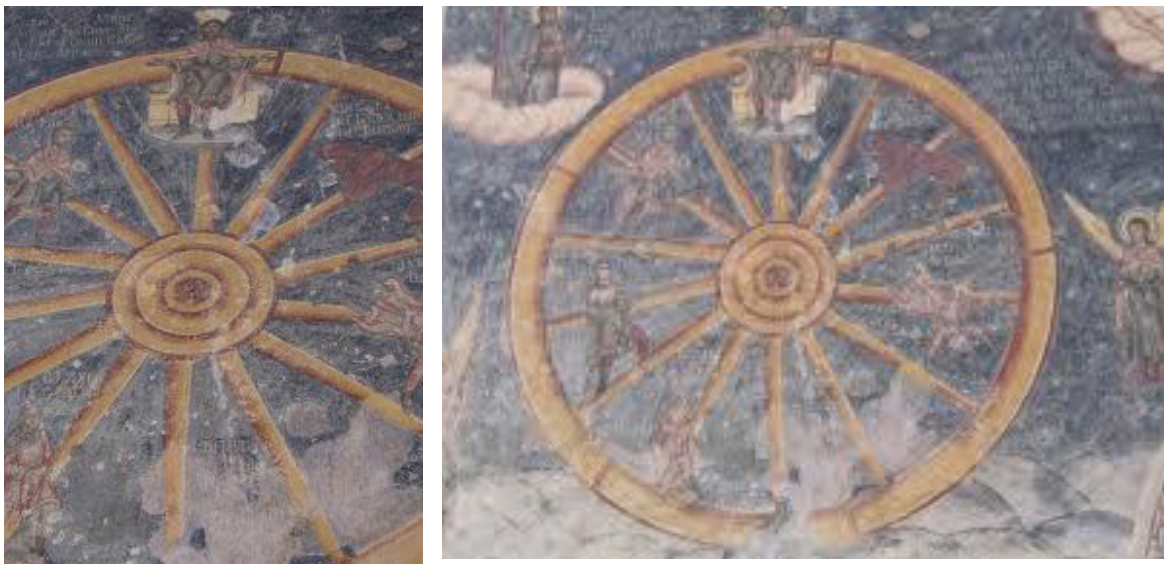

Figures 3 and 4: The wheel of life represented by Grigore Ranite at the Black Church in Brașov, 1733-1734 and at St. Parascheva Church in Rășinari, 1758.

The painting school of Abrud was founded by Simion Silaghi towards the end of the century. Simion Silaghi had many apprentices, among them his three sons, but also other painters from the region of Apuseni where he had his workshop: Ion and Nicolae Cuc, Nicolae and Nechifor Bădău, Gheorghe S,pan, Motok Karoly are only some of them.

Other painting schools developed in the neighbouring regions of Maramureș and Banat. In Maramureș, Ruthenian painters were active as Alexandru Ponehalschi and his Romanian apprentice Radu Munteanu, whereas in Banat there were mostly Serbian painters, like Stefan Tenecki, Nedelcu Popovici, Toader Crăciun etc. Sometimes these painters also received commissions in Transylvania. They either went there themselves, or they worked on the commissions they received in their workshops and later delivered them to their donors.

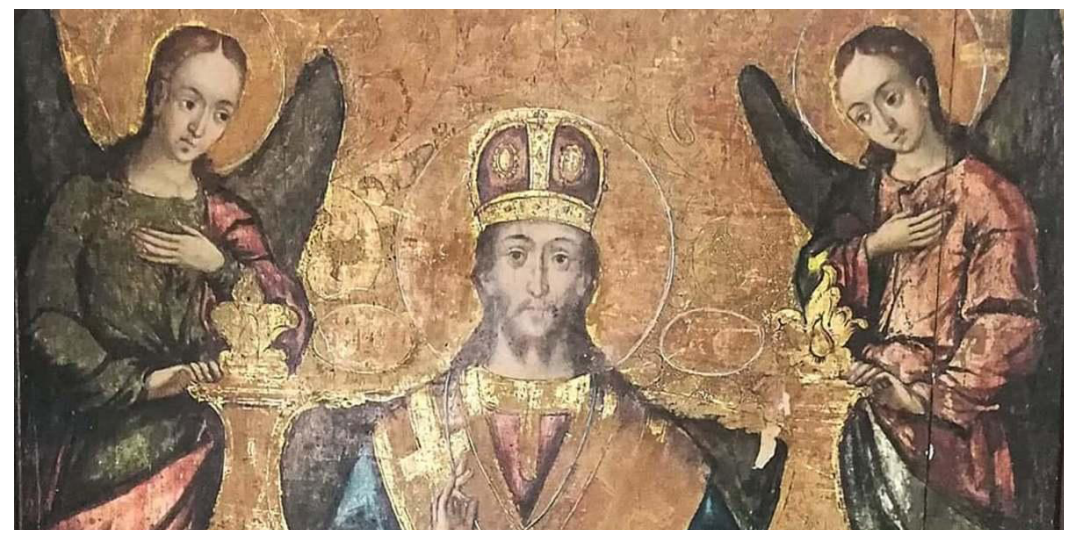

Fig. 5: The altar of the Blaj Greek Catholic Cathedral by Stefan Tenecki 


\section{The Political and Social Context of the Period}

During the period of Ottoman-Habsburg wars of the sixteenth to eighteenth centuries, Habsburg policy towards Eastern Orthodox Christians was often marked by special interests, related to complex religious situations in various regions. ${ }^{12}$

During the eighteenth century, Eastern Orthodox communities in major Austrian cities were made up mainly of ethnic Greeks, Serbs and Romanians. The Orthodox were first placed under the spiritual jurisdiction of the Metropolitanate of Karlowitz. Later development led to the creation of autonomous and particular jurisdictions, thus establishing separate parishes for different ethnic communities.

The Habsburg monarchy had developed during the previous two centuries around the Catholic religion which laid the foundation of the monarchy. ${ }^{13}$ Empress Maria Theresa followed the traditional path despite her administrative, religious and economic reforms in $1749 .{ }^{14}$ Though a pious Catholic, she sought to bring the church under state control and clerics were no longer exempt from paying taxes. She also insisted on the need for education.

Even before these reforms, The Metropolitan of Karlowitz, Arsenie IV Jovanovic was concerned with the priests' level of education and that of the believers therefore he founded an academy in Karlowitz in 1733 where painting was also taught. ${ }^{15}$ While the first official painters of the Metropolitanate had studied with Russian teachers, the next generation was taught by teachers from Kyiv Caves Lavra. Painters such as Stefan Tenecki from Lipova, considered the court painter of the bishop of Arad, was educated at the Caves Lavra and possibly also at the Vienna Academy. At the Metropolitanate, the official style was set by painters from the Lavra.

During the coregency and after Empress Maria Theresa's death, Emperor Joseph II continued the reforms along the lines pursued by his mother. Joseph's policy aimed at greater religious toleration and suppression of religious institutions and customs deemed contrary to Enlightenment

\footnotetext{
${ }^{12}$ Sima Ćirković, The Serbs (Malden: Blackwell Publishing, 2004).

${ }^{13}$ For an in-depth analysis see: Anna Coreth, Pietas Austriaca (West Lafayette: Purdue University Press, 2001).

${ }^{14}$ Charles O’Brien, "Ideas of Religious Toleration at the Time of Joseph II. A Study of the Enlightenment among Catholics in Austria," Transactions of the American Philosophical Society 59, no. 7 (1969): 17-18.

${ }^{15}$ Vladimir Cvetkovic, "The Serbian Tradition" in The Orthodox Christian Orthodoxy, ed. Augustine Casiday (London: Routledge, 2012), 135.
} 


\section{Raluca Prelipceanu}

principles. Following the Edict of Tolerance issued in 1781, the Orthodox gained important rights such as that nobody could compel them to convert to Catholicism or take their churches by force. ${ }^{16}$

These changes were not tailored to Transylvanian needs as they represented the global policies of the Habsburg Empire and impacted all the lands under their jurisdiction.

\section{Sources of Inspiration: The Role of Schools and Books}

Orthodox Serbs were granted privileges that other Orthodox nations under Habsburg rule did not enjoy. This explains why they were more open to Western influences. ${ }^{17}$ At the same time, the Russian teachers were likely to have been strongly influenced by Tsar Peter's reforms of 1722 contained in a Gramata. ${ }^{18}$ The teachers from the Kyiv Lavra were equally influenced by Western art as many Western models were copied and taught at the school of the Lavra.

First of all, changes in Ruthenian art were coming from the newly formed Greek Catholic Ruthenian church which adopted Catholic models. The Greek Catholic Council of Zamosc set some rules for the liturgical services and the church paintings. The report of this council was published in Vilnius and Suprasl in 1722 and later in Univ, Liov and Poceaev. ${ }^{19}$ Some of its decisions were also adopted by the Orthodox church.

New subjects never treated before in the Orthodox art were now introduced. The iconography of the Passions of Christ was highly developed with a special emphasis on the Flagellation. Christ's feet on the cross were separated and pierced by nails. Some Catholic saints began to be represented as well. Also, compositions like Mater Dolorosa and God the Father were common. Christ and the Virgin were usually crowned and sometimes Christ is painted with the orb and the stick as attributes of power and baroque decorations adorn Orthodox icons. ${ }^{20}$

\footnotetext{
${ }^{16}$ Daniel Dumitran, "Transylvanian Reactions to the Tolerance Act of Emperor Joseph II," Annales Universitatis Apulensis, Series Historica 8 (2004): 91-93.

${ }^{17}$ Remus Câmpeanu and Ana Câmpian, eds., In spiritul Europei moderne. Administrația și confesiunile din Transilvania in perioada reformismului terezian și iosefin (1740-1790) [In the Spirit of Modern Europe. The Administration and Confessions in Transylvania during the Period of Theresian and Josephine Reforms (1740-1790)], (Cluj Napoca: Presa Universitară Clujeană, 2009).

${ }^{18}$ Waldemar Deluga, Ukrainian Painting Between the Byzantine and Latin Traditions (Ostrava-Warsaw: Archeobooks, 2019), 115.

${ }^{19}$ Idem, "L'évolution de l'iconographie dans l'église gréco-catholique pendant le XVIIIe siècle à la lumière des sources écrite," Revue des études slaves 71, no 2 (1999): 229-30.
}

${ }^{20}$ Ibidem. 
On the other hand, the Orthodox tried to respond to the Catholic attempts to gain control over the church in Ruthenia by employing Protestant carvers and printers. They introduced images developed in the Protestant world by well-known engravers such as Albrecht Dürer, Lucas Cranach and Hans Holbein the Younger. ${ }^{21}$ Some of the most important works that inspired the painters of this period were Biblia Ectypa, Thesaurus, Theatrum Biblicum and Biblia Piscator. ${ }^{22}$

There was an especially great mobility of engravers within the Romanian space during the seventeenth and eighteenth centuries. Peter Mohyla, Prince of Moldavia, became Metropolitan of Kiyv in $1632 .{ }^{23}$ Peter Mohyla sent teachers as well as printers and woodcarvers to Wallachia and Moldavia where his father and uncle had been princes and also to Russia. ${ }^{24}$ They mainly reprinted the books that had been printed in the Ruthenian lands only a few years before and reproduced the same wood carvings. $\mathrm{He}$ also sent books to Transylvania.

According to Philip Zweig, many itinerant Ruthenian painters went to the neighbouring regions of Hungary, Transylvania, and Serbia where they opened painting schools. ${ }^{25}$ Although these schools were mere workshops, each painter had a number of apprentices. Most of the painters were not educated in official schools like the school of the Kyiv Caves Lavra, another in Karlowitz or the Academy in Vienna, but private workshops.

One source of spreading new ideas besides the workshop was the canonical visitations of the bishops who could give directions regarding what could and what could not be represented in churches. Also, the priests who were ordained by Serbian bishops in Buda, Arad or Timișoara were probably educated in that respect before their ordination as the Metropolitanate of Karlowitz was also concerned with the art promoted in churches and with the message delivered to the faithful, as shown by Berezhnaya and Himka. ${ }^{26}$ Also, the Protocols of the canonical visitations in Abrud ${ }^{27}$ and

${ }^{21}$ Ibidem, 232-33.

${ }^{22}$ Ibidem.

${ }^{23}$ Ihor Sevcenko, "The Many Worlds of Peter Mohyla," Harvard Ukrainian Studies 8, no. 1/2 (June 1984): 9.

${ }^{24}$ Petru P. Panaitescu, Petru Movilă și românii (Peter Mohyla and the Romanians), (București: Tipografia Cărților Bisericești, 1942).

${ }^{25}$ Philip Zweig, Icônes, XI-XVIII siècles (New York: Parkstone International, 2004), 130.

${ }^{26}$ Berezhnaya and Himka, The World To Come, XXV.

27 "Protocolul Vizitației Canonice a episcopului Ghedeon Nichitici. Protopopiatul Abrud, protopop Iosif Adamovici, 1787”, in Ilarion Pușcariu, Documente pentru limbă și istorie (Documents for Language and History) vol. 1 (Sibiu: Tiparul Tipografiei Arhidiocezane, 1889). 


\section{Raluca Prelipceanu}

Ponor ${ }^{28}$ prove the engagement of the bishops in this line. Later, the correspondence between Metropolitan Andrei Șaguna and priest Moga from Covasna equally proves the concern of the ecclesiastical authorities concerning church paintings. ${ }^{29}$

Both the scriptures and the apocryphal literature were sources of inspiration for the scenes developed during this period. One of the most important was the Apocalypse of Basil the New which contained a thorough description of the torments suffered by the sinners in hell that inspired many of the compositions of the Last Judgement. ${ }^{30}$ The Apocalypse of St. Basil the New inspired some of the painters from Maramureș and elsewhere, as for example the painting of the church in Răşinari.

As Orthodox painters tended to copy and wanted to be equal to painters from other confessions, especially the official Catholic painters of the Imperial Court, they were influenced by their art and their ideas, and one can notice modern Baroque influences and Western Catholic elements that were introduced in the Orthodox art.

\section{The Changes in Art}

What then, was the impact of these changes on Romanian painters from Transylvania? To answer this question, one can begin by looking closely at the work of one of these Orthodox painters, Simion Silaghi. Simion Silaghi was probably born in the region of Sălaj. He was an apprentice to Andrei Bo(...)dor who held a workshop nearby Cluj.

He had a long and prolific career. He began his career by painting alongside his master in his birth region and nearby Cluj. He later worked with Gheorghe son of Iacov in Albac in 1778 and moved to Abrud mid1780s where he opened his own painting workshop.

There is a continuous evolution in his career, but some Western elements can be observed in his art from the very beginning, like the representation of the scene of the Coronation of the Virgin either in the sanctuary, or at the iconostasis, or on the vault of the nave or on that of the exonarthex. The Coronation of the Virgin illustrates the Immaculate Conception doctrine and ap-

\footnotetext{
${ }^{28}$ Alexandru Gherghel, Monografia istorică a bisericii Sf. Nicolae din comuna Ponor, Raion Aiud, Regiunea Cluj (The Historical Monography of St. Nicholas Church in Ponor), (Sibiu, 1958).

${ }^{29}$ Ana Grama, "Documente arhivistice sibiene (1850-1870). Donații din țară și conflicte cu autoritățile locale în județul Covasna (1851-1859)" [Documents from the Archives of Sibiu (1850-1870). Donations from the Country and Conflict with Local Authorities in the Region of Covasna (1851-1859)], Angvstia I (1996), 165-86.

${ }^{30}$ Himka, Last Judgement Iconography in the Carpathians (Toronto: University of Toronto Press, 2009), 46-49.
} 
peared first in the Western world, as early as the twelfth century in the English and the French spaces. ${ }^{31}$ In the Western world, a heresy called Pelagianism developed that denied the fact that the original sin was inherited by all men. St. Augustine tried to fight this heresy and later his writings were developed during the twelfth century by Anselm of Canterbury. In the following century, John Duns Scottus also developed the doctrine of the Immaculate Conception, rejected by Thomas Aquinas and the Dominicans. ${ }^{32}$ The Coronation of the Virgin illustrates the fact that the Virgin, due to her immaculate conception, is raised upon death with her body to heaven where she is crowned as empress in the early compositions by Jesus and following the fifteenth-century Council of Ferrara Florence in 1438-1439 by the Holy Trinity, as a possible Eastern influence brought by monk Barsanuphius and his adepts. ${ }^{33}$ This composition is widely spread in the eighteenth century Transylvanian paintings.

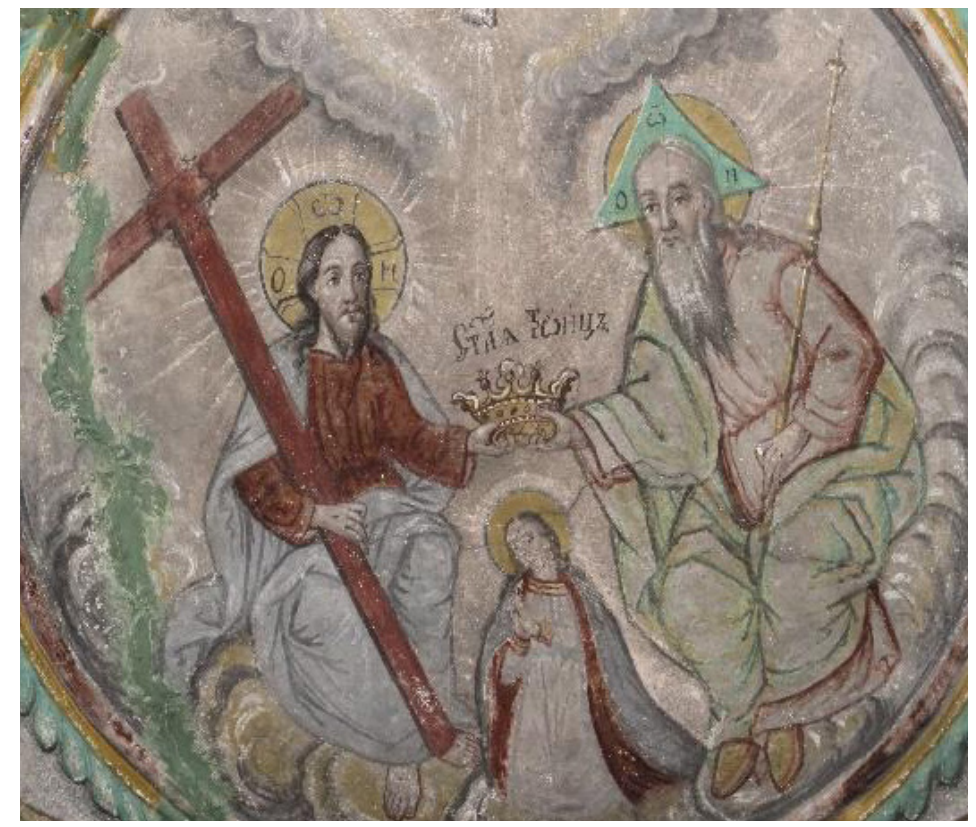

Fig. 6: The Coronation of the Virgin, vault of the nave, Vidra Poieni, 1792

\footnotetext{
${ }^{31}$ Thomas Alexander Heselop, "The English Origins of the Coronation of the Virgin," The Burlington Magazine 147, no. 1233 (December 2005), 790; Émile Mâle, L'art religieux de la fin du Moyen Âge. Étude sur l'iconographie du moyen âge et sur ses sources d'inspiration (París: Armand Colin, 1995).

${ }^{32}$ Ignatus Brady, "The Development of the Doctrine of the Immaculate Conception in the Fourteenth Century after Aureoli," Franciscan Studies 15, no. 2 (1955): 175-202.

33 Jean Le Pichon and Yann Le Pichon, Le mystère du Couronnement de la Vierge (Paris: Ed. Robert Lafont et Le Centurion, 1982), 36.
} 


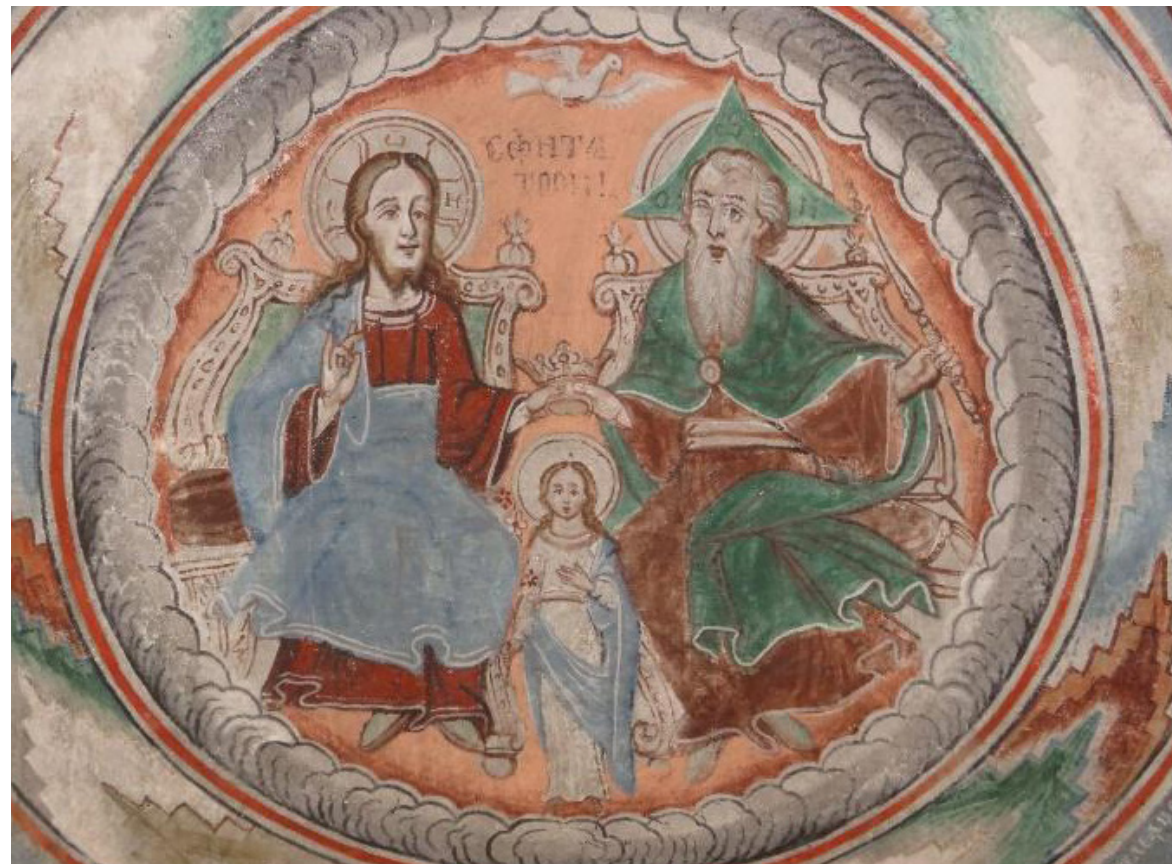

Fig. 7: The Coronation of the Virgin, vault of the sanctuary, Vința 1819-1821

Simion Silaghi paints it in all his iconographic programmes by depicting three subtypes: either the Virgin standing between God the Father and Christ with the dove of the Holy Ghost above her, crowned only by Christ or crowned by both God the Father and Christ, or the Virgin kneeling and crowned by both God the Father and Christ. ${ }^{34}$

This composition departs from the traditional Eastern representations of the death of the Virgin illustrated in the icon of the Dormition of the Mother of God. The Virgin is represented in the centre of the image on a bed with the apostles gathered around her, and Christ in their midst holding in his arms her pure soul. Sometimes, the composition is more developed showing also the Apostles coming on the clouds up high, or in the lower part the punishment of the Jew Iahonnias who wanted to reverse the bed and had his hands cut off by an angel.

In the 1790s, Silaghi also paints an icon of the Dormition of the Mother of God for a church in Abrud with the apostles gathered around her bed, but her soul is represented up in heaven flying towards Christ's open arms. He is no longer in the midst of the apostles.

\footnotetext{
${ }^{34}$ For a typology see: Louis Réau, Iconographie de l'art chrétien. Tome II Iconographie de la Bible (Paris: PUF, 1957), 622.
} 
At a later stage of his career, he also integrated the scene of the Immaculate Conception represented in the apse of the sanctuary or under the apse, a scene promoted by the Catholic Counter-Reformation. This time the Virgin is represented standing upon the crescent moon. She wears a crown of twelve stars and smashes the head of the serpent that had tempted Eve. This kind of composition underlines the opposition between the Virgin and Eve and becomes the official image of the Immaculate Conception after the Post-Tridentine Council. ${ }^{35}$

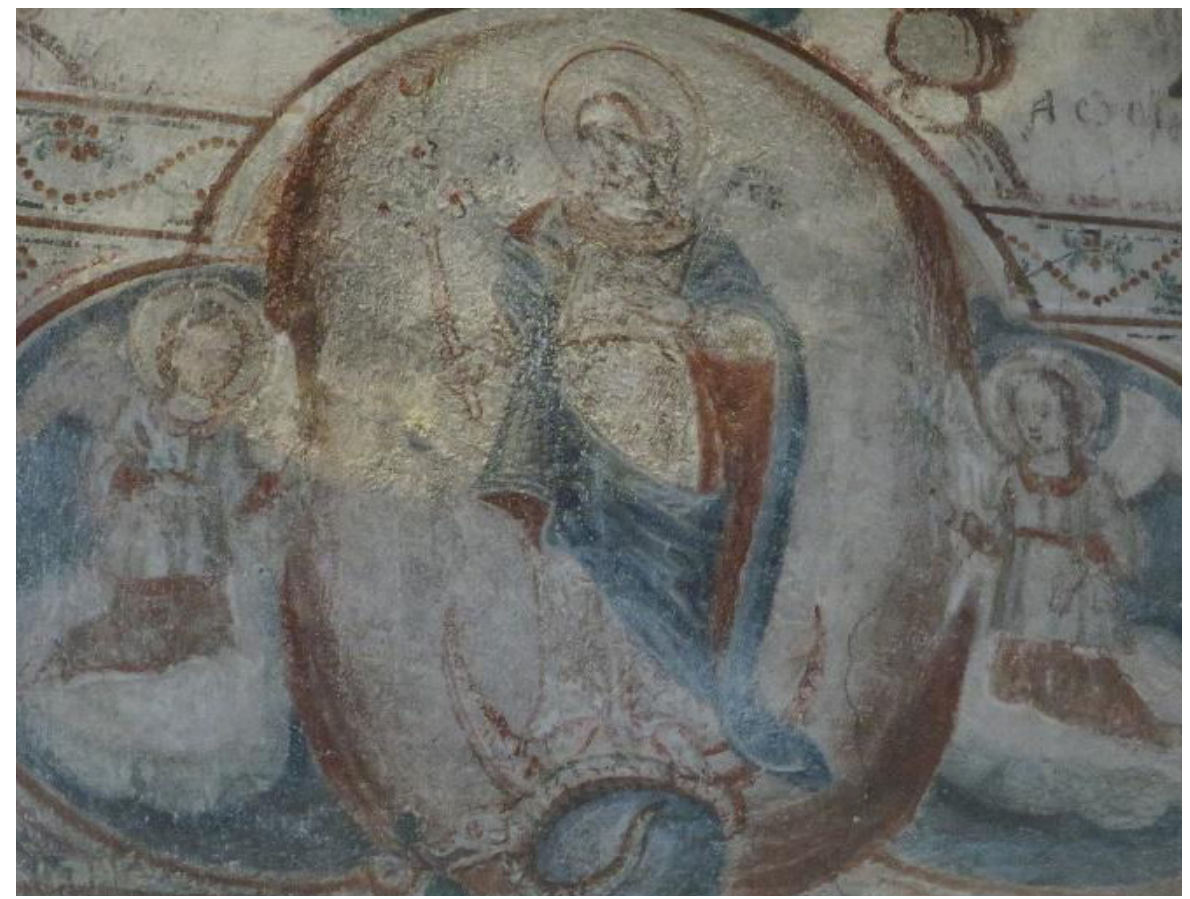

Fig. 8: The Immaculate Conception, apse of the sanctuary, St Michael Church, Vința, 1819-1821.

Also, the image of the Weeping of the Mother of God or Mater Dolorosa is often represented during this period. ${ }^{36}$ Engravings on the subject were widely spread in Transylvania, either coming from abroad or as a product of the Blaj guild of engravers and the image was largely promoted by the Jesuits in their circles. Simion Silaghi painted a Stabat Mater image at the iconostasis of the church in Lupsa.

${ }^{35}$ Ibidem, 79-82.

${ }^{36}$ Dumitran, Enikő Hegedüs and Vasile Rus, Fecioarele innlăcrimate ale Transilvaniei (The Weeping Virgins of Transylvania), (Alba Iulia: Ed. Altip, 2011). 


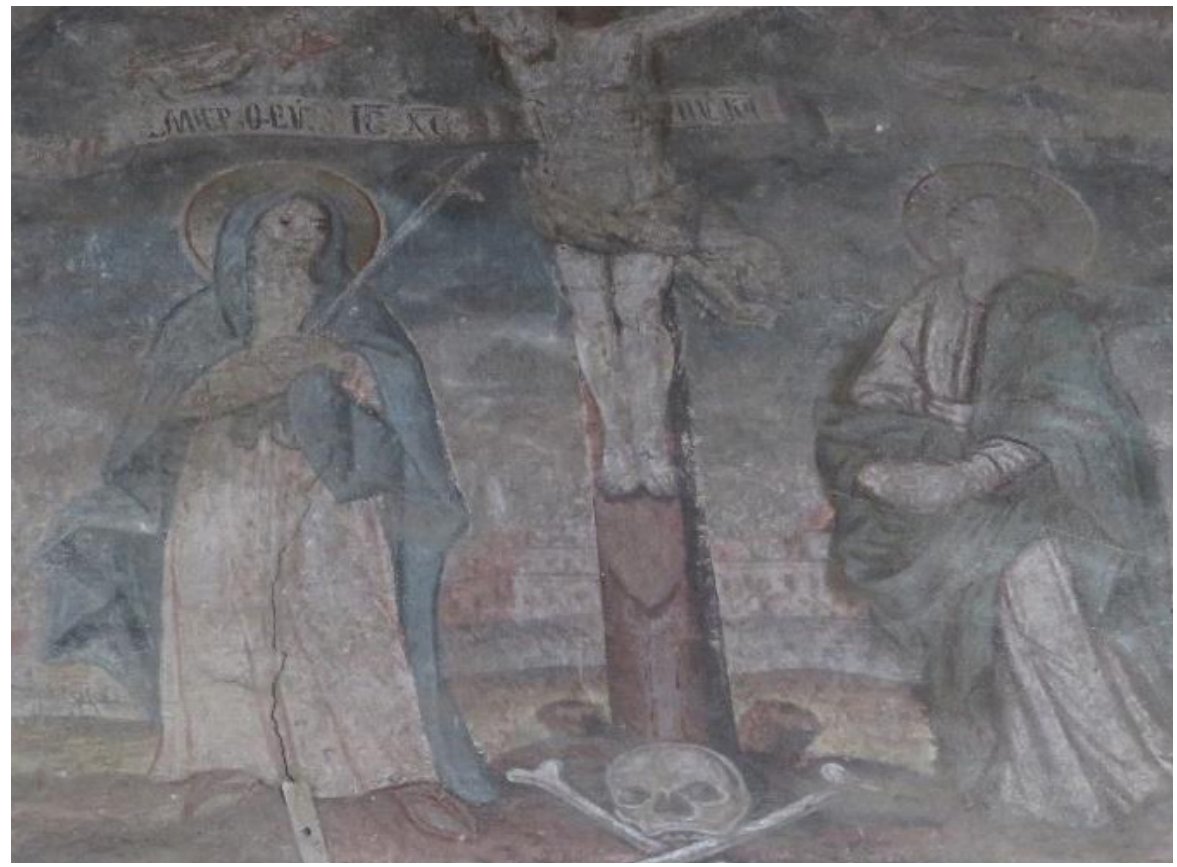

Fig. 9: The Crucifixion, Iconostasis, St George Church in Lupșa, Simion Silaghi and his son Simion, 1810.

Other elements of Catholic inspiration painted by Simion Silaghi were the Arma Christi whom he painted on the triumphal arch of several churches, including the Holy Chalice and Veronica's handkerchief and

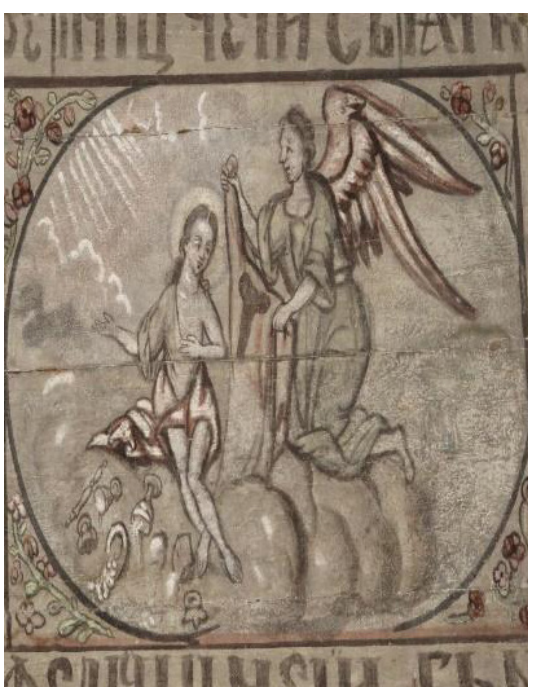

Fig. 10: Blessed are the poor in the heart, Gârda de Sus, 1804

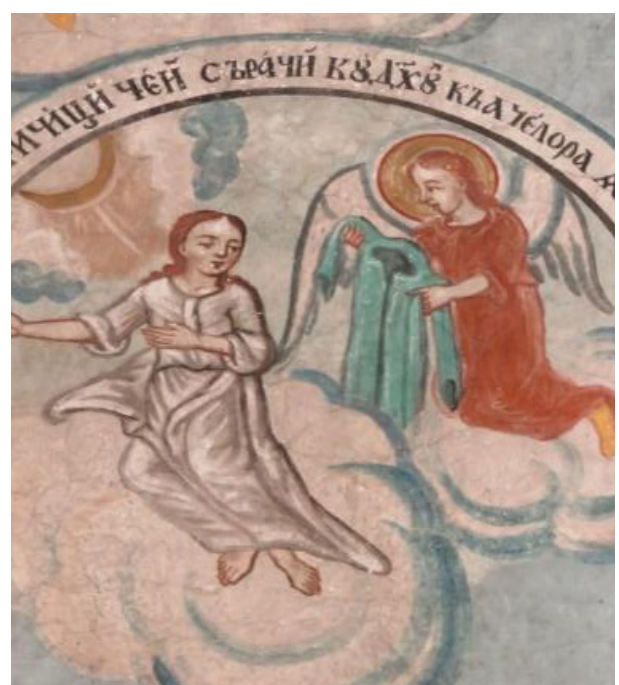

Fig. 11: Blessed are the poor in heart, Ponor, 1823 
the Beatitudes anthropomorphised, also represented on the triumphal arch. For the composition of the Beatitudes, he was inspired probably by Stefan Tenecki, whom he probably met towards the end of the latter's life, as Tenecki was buried in the graveyard of the parish whose member Simion Silaghi used to be. In his turn, Tenecki was inspired by the engravings of Christoph Weigel for the 1695 Biblia Ectypa printed in Augsburg. ${ }^{37}$ Tenecki had studied at the Caves Lavra School, where he probably also came into contact with such books and engravings.

Also, the depiction of The Prosternation of the Twenty-Four Elders from St John's Book of Revelation that is depicted both in Vința and Ponor is likely to be of Western influence. The scenes are very different. Whereas in Vința the elders are represented in two parallel rows on the vault of the nave directed towards the scene of the Last Judgement, in Ponor they are represented in two groups of twelve on either side of the throne of God before which stand the seven lamps. The four living creatures also appear in this scene. This kind of eschatological scenes developed in Western art from the fourth until the thirteenth century when it was replaced by the Last Judgement scene and later passed into engravings which were also probably the source of inspiration for the scenes painted by Simion Silaghi.

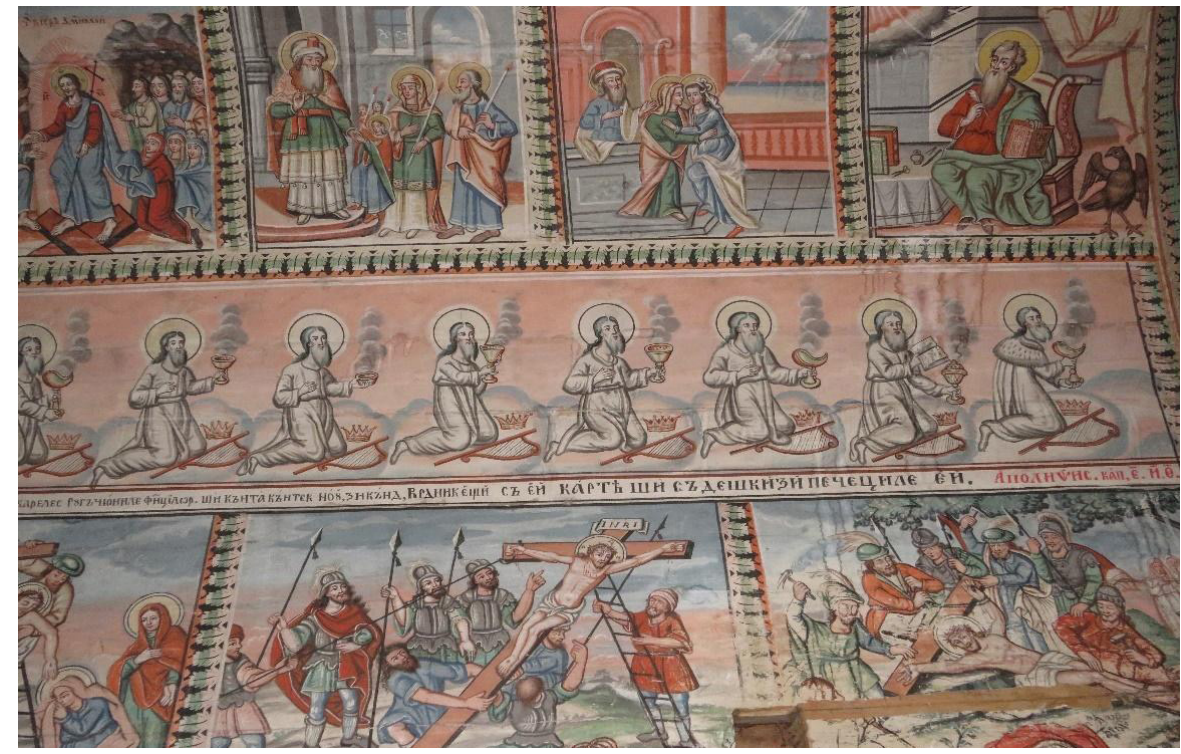

Fig. 12: The Prosternation of the Twenty-Four Elders in the nave, Vința, 1819-1821.

${ }^{37}$ Jovana Kolundžija, "Moştenirea pictorului Stefan Tenecki în Episcopia Sremului” (The Heritage of Stefan Tenecki in the Eparhy of Srem), in Patrimoniu si patrimonializare, ed. Elena Rodica Colta (București: Editura Etnologică, 2018), 42-63. 


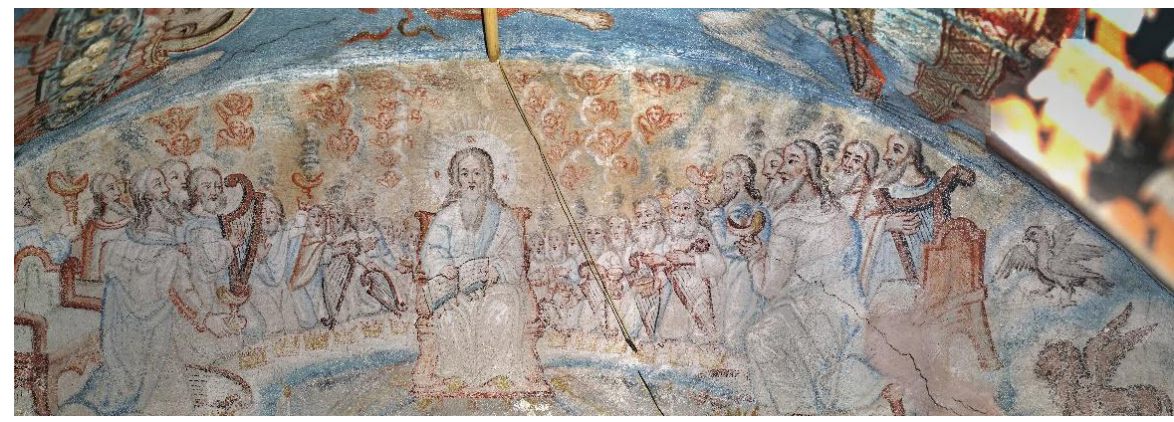

Fig. 13: The Prosternation of the Twenty-Four Elders, western wall, nave, Ponor, 1823.

Other scenes traditionally depicted in the Orthodox iconographic programmes were transformed according to the Catholic models as the scene of the Annunciation wherein the traditional Orthodox programmes the Virgin was represented either at the fountain or weaving, whereas Silaghi and other Transylvanian painters before him, as Gheorghe son of Iacov, represent her reading as in the Western tradition. This representation had also been adopted in the Wallachian art, in the new Brancovan style of the eighteenth century as Cornelia Pillat ${ }^{38}$ notes. Also, the direct perspective coexists now with the traditional reverse perspective of the Orthodox icons. This characteristic is also underlined by Waldemar Deluga ${ }^{39}$ in the case of the Ukrainian icons of the same period.

Among the Western elements of the compositions are the fact that the Virgin is represented bareheaded, the position of her hands in devotional prayer as in the Catholic tradition, the representation of God the Father, a practice against Orthodox rules as reasserted by the Moscow Council during the seventeenth century, the fact that the Virgin wears a crown and not only in the compositions of the Coronation of the Virgin or the Immaculate Conception, but also in the traditional Platytera composition of the apse of the altar. Judith Herrin ${ }^{40}$ notes that in Byzantine iconography, the Virgin is never represented with the regalia, not to compete with the Byzantine empress. Therefore, the regalia only appear in the Western representations. Furthermore, Christ or God the Father holds the symbols of earthly power which is a characteristic of the Western iconography, as is the representation of Christ with the stigmata.

\footnotetext{
${ }^{38}$ Cornelia Pillat, Variațiuni pe teme date în arta medievală românească (Variations on some Given Themes in the Romanian Medieval Art), (București: Vremea, 2003), 124-25.

${ }^{39}$ Deluga, Ukrainian Painting, 61.

${ }^{40}$ Judith Herrin, "The Imperial Feminine in Byzantium," Pastङ Present 169 (November 2000): 3-35.
} 
The flower held by the Virgin symbolizing purity is also an element of Western inspiration. Also, the instruments of martyrdom held by the apostles are of Western inspiration and can be found in Byzantine iconography as early as the sixteenth century in the paintings of the Dionisiu monastery from the Holy Mountain, whose donor was Ruxanda, the wife of the Moldovian prince Alexandru Lăpușeneanu. ${ }^{41}$ St. Bartholomew for example is painted holding in his hands the skin of his head. According to Western tradition, he died by flaying, whereas in the Byzantine tradition, he was crucified. ${ }^{42}$

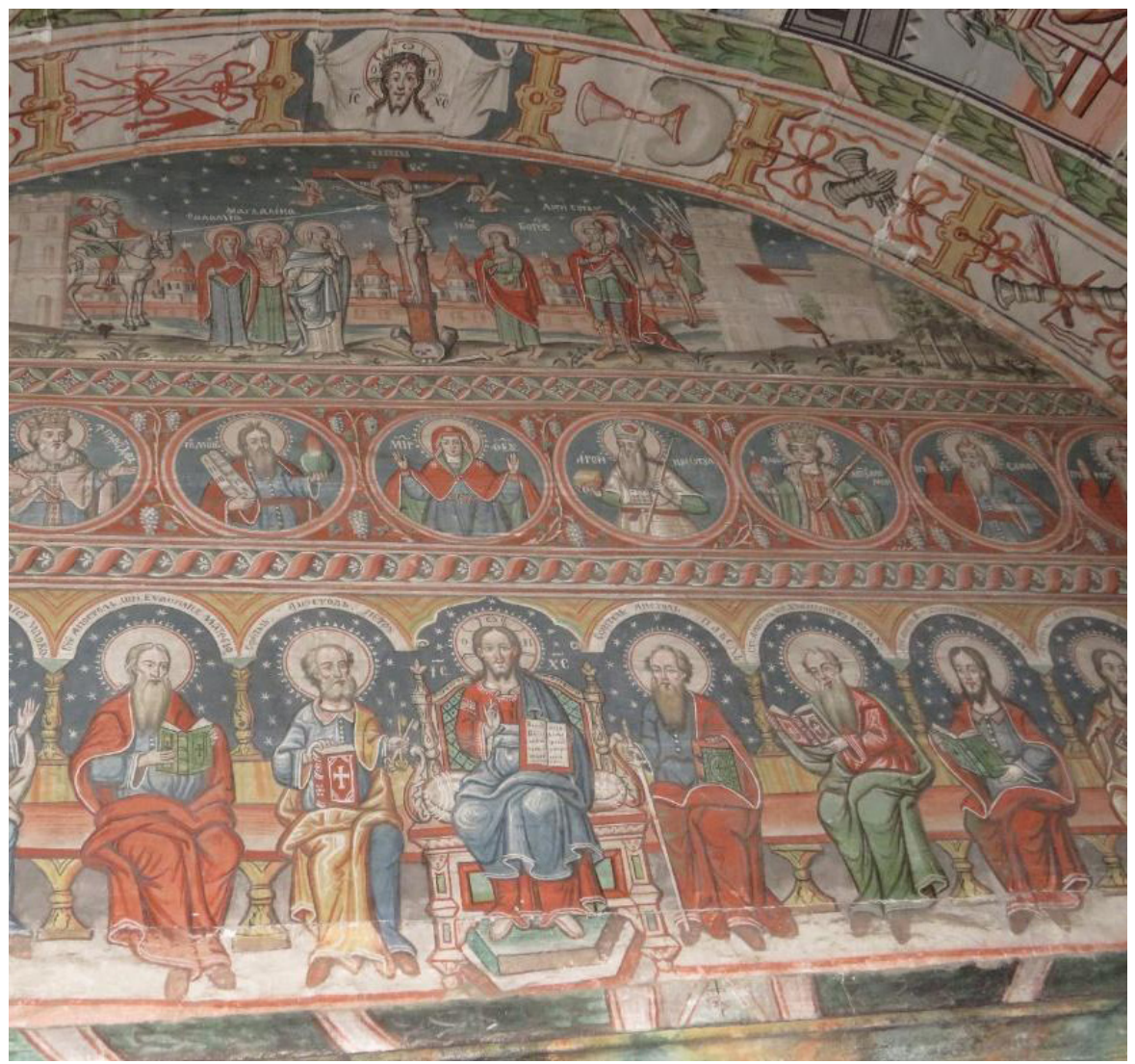

Fig. 14: The Prosternation of the Twenty-Four Elders, western wall, nave, Ponor, 1823

${ }^{41}$ Sarah Kay, "Original Skin: Flaying, Reading and Thinking in the Legend of St. Bartholomew and Other Works," The Journal of Medieval and Early Modern Studies 36, no 1 (Winter 2006): 35-73.

${ }^{42}$ Petru Sofragiu, "Synaxarion in the Narthex Frescoes of Dionysiou Monastery from Mount Athos," Analele Știintifice ale Universității "Alexandru Ioan Cuza" din Iași - Matematică 2 (March 2021): 155-70. 
Furthermore, Simion Silaghi's compositions are filled with Baroque elements like the decorations, the lavish clothes or the style of the buildings and the natural elements. He is also inspired by apocryphal writings, such as the legend of the fourth magus or that of the Holy Grail which he reproduces in the Crucifixion scene from the church in Vința.

But were all these changes due only to external factors or was there a change of taste inherent to the fact that several nations and confessions were cohabiting? A possible answer seems to come from the church in Lupșa, initially painted by priest Gheorghe Tobias from Abrud in 1750. The inscription reads "this sanctuary was painted in 1750 at the expense of the faithful Olia Ion from Lupsa who paid eighteen florints for his eternal memory. Ion, Petca, Salomiia, Petca, Matei, Simziana [?], Andrei, Nicolae, Filimon, Ioana." ${ }^{33}$ The donors were generally the community, the priest and the bishop as church inscriptions testify. ${ }^{44}$

The painting was redone in 1810 by master Simion Silaghi and his son Simion. They only painted the sanctuary and the iconostasis, but if the painting previously done by Gheorghe Tobias was in line with the Orthodox tradition, this time a lot of elements of Catholic influence were included in the iconographic programme, like the Immaculate Conception on the vault of the sanctuary, Mater Dolorosa at the iconostasis, or the Sacred Heart of Jesus on the triumphal arch. They coexisted with Orthodox elements as the representation at the iconostasis of a stylite saint, probably Symion. To the best of anyone's knowledge, this is the iconographic programme closest to the Catholic dogma that Simion Silaghi had ever painted. Interestingly, the sanctuary was painted at a time when the church was still Orthodox. It only became Greek Catholic in 1827. Should we consider this evidence of the painter's and the priest's and community's free choice?

\section{A Semantic Analysis of Painters' Signatures}

This period is characterized by the aspirations for upward social mobility of Romanian intellectuals, since the new Greek Catholic elite was educated in Western schools. Church painters worked both for Orthodox and Greek

\footnotetext{
43 The inscription writes in Romanian in the Cyrillic alphabet: „Iar la an 1750 s-au zugrăvit acest sf. oltar din cheltuiala unui creştin de aici din Lupşa, anume Olia Ion au dat 18 florinţi ca să fie veacinică pom[enire]. Ion, Petca, Salomiia, Petca, Matei, Simziana [?], Andrei, Nicolae, Filimon, Ioana". The inscription refers only to the paintings in the altar.

${ }^{44}$ Ioana Cristache Panait, “Tipuri sociale și aspecte de critică socială în pictura monumentelor de lemn din centrul și vestul țării” (Social Types and Aspects of Social Criticism in the Painting of the Wooden Monuments from the Centre and Western Parts of the Country), Revista muzeelor și monumentelor - monumente istorice și de artă 15, no. 1 (1984): 54.
} 
Catholic churches and they aspired as well at upward social mobility. How do we know this? Because of the changes in art, but also by the semantic analysis of the signatures.

Some painters as Iacov from Rășinari seemed to assume aristocratic titles, as he begins to sign his works using the title of boyar, a local nobleman. The title was further used only by his eldest son, Gheorghe. ${ }^{45}$ Another painter, Simion Silaghi also assumed the title of painter of Abrudbania.

This was not unusual for the Orthodox painters under Habsburg rule; for example, the well-known painter from Muncaci, Ilia Brodlakovici Vişenski used to sign himself „maljar Mukachevskyj” ${ }^{46}$ and the painters usually attached to their name the name of their region or place of origin as did Toader and Iacov Ciungar or Father Nicolae of Feisa. This was common use both for the Ruthenian and the Transylvanian painters.

At the same time, the foreign appellatives of Piktor of Latin influence and Mabler of German influence were often employed by the painters. The old appellative zugrav or zograf of Slavic origin was still largely employed, as proven by the signatures of Stan or Iacov from Răşinari. But sometimes the same painter would employ several different appellatives as in the case of Simion Silaghi who signed both piktor and zugrav, perhaps depending on the community that commissioned the work, while Stefan Tenecki's name appears in the official documents with the appellative of Mahler or Maler. ${ }^{47}$ The same was true for the Ruthenian painters Andrei Haljeckyj and his son, Nicolai Hajeckyj, ${ }^{48}$ or for Marco Shestakovych. ${ }^{49}$ Also, during the eighteenth century, there was a painter in Maramureș who was called Ioan Maliar (John the Painter). Furthermore, Simion Silaghi also appealed at times to the Magyarization of his name, signing Simon Szylagi like in the Hungarian language. ${ }^{50}$

Ana Dumitran ${ }^{51}$ notes that "The Magyarization of the name in official situations, the signing of the artworks being one such situation, is the fruit

\footnotetext{
${ }^{45}$ Dumitran, Cucui, Mihu, Pop, Iacov Zugravul, 28.

${ }^{46}$ Iconography. Sacred Painting in Subcarpathian Ruthenia (Byzantine Seminary Press), https://archpitt.org/iconography-sacred-painting-in-subcarpathian-ruthenia/, accessed November, 2021.

${ }^{47}$ Porumb, Dicționar de pictură veche românească din Transilvania, (Dictionary of Old Romanian Painting from Transylvania), (București: Editura Academiei Române, 1998).

${ }^{48}$ Iconography, https://archpitt.org/iconography-sacred-painting-in-subcarpathian-ruthenia/, accessed November, 2021.

${ }^{49}$ Berezhnaya and Himka, The World To Come, XIV.

${ }^{50}$ Dumitran, "Pictorul Simion Silaghi-Sălăgeanu," 191.

${ }^{51}$ Dumitran, "Pictura românească în județul Alba până la mijlocul secolului al XIX-lea. Demersuri pentru o bază de date" (The Romanian Painting from the Region of Alba until mid $19^{\text {th }}$ Century. Approach for a Database), Patrimonium Apulense 12 (2012): 62.
} 


\section{Raluca Prelipceanu}

of the awareness of their self-value and the urge to deliver services at the level of those meant for the privileged".

The analysis of the signatures of Simion Silaghi suggests that the choice might have been influenced by the composition of the donor community. For example, one of the questions we asked ourselves was why Simon Silaghi signed the icon of the Virgin he painted for the church in Roșia Montană in 1780 with the Latin appellative as he did in the case of the icons painted for example for the church

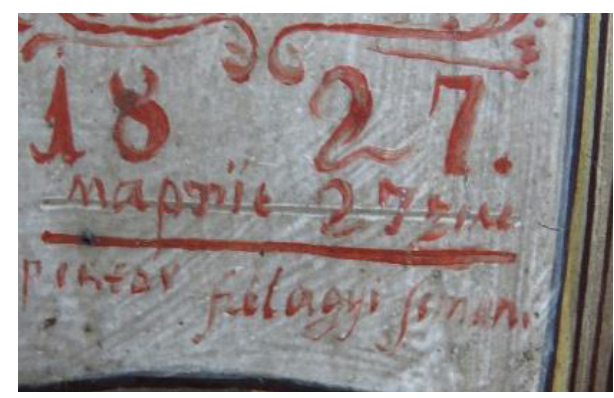

Fig. 15: Simion Silaghi's signature on the icon of Christ from the church in Bucium Muntari 1827. in Bucium Muntari in 1827 and 1829, while he signed the Pantocrator icon in 1825 for the church in Corna, which is very close to the other two locations with the traditional appellative of zugrav? In our opinion, the first two communities only had Orthodox churches at the time when Silaghi painted the icons, attended by mixed communities, while in Corna there were both an Orthodox and a Greek Catholic church, so the communities were clearly separated..$^{52}$ Also, the region was rich with mines which attracted many foreigners. This is why eighteenth-century Abrud and its neigbouring localities were characterized by a cosmopolitan environment since they also had German, Italian and French inhabitants..$^{53}$

\section{Conclusion}

The changes in the pictorial programmes that occured during this period underlie a desire to align to the pictorial programmes of the Catholic churches of the ruling class. The compositional types that developed and the style of the new Western Baroque led to a different self-perception, a rising awareness of the value of the painters and an increase in their self-esteem.

Not only are new compositions adopted, but some are also modified according to the new tastes and furthermore, the first self-portraits were painted during this period. In Wallachia, the famous painter Pafnutie had already painted several self-portraits at the end of the seventeenth century.

\footnotetext{
52 Sematismul veneratului cler al arhidiecezei metropolitane greco-catolice române de Alba Iulia și Făgăraș (The Schematism of the Venerable Clergy of the Metopolitan Romanian Greek Catholic Bishopric of Alba Iulia and Făgăraș), (Blaj: 1900).

53 Teofil Frâncu and George Candrea, Românii din munții Apuseni, (The Romanians of the Apuseni Mountains), (Bucuresci: Tipografia Modernă Gr. Luis, 1888), 39.
} 
Tenecki painted in Banat the first self-portrait in Serbian art in 1770, also Radu Munteanu painted a self-portrait in Maramureș in 1782 and Ștențel Condrat painted his self-portrait in Transylvania in $1818 . .^{54}$

Was the change in art triggered by the change of status or the reverse? The evidence suggests that the change in art may have been partly imposed by church authorities and partly freely assumed by local communities and priests who were the main donors of the works. Transylvania was a land of overlapping cultures and the coexistence of several cultures and confessions meant exchanges and reciprocal influences. Changes in art may have come from a change in taste, the tastes of Romanians growing closer to those of other nations with whom they shared the land. On the other hand, the change in art may show a desire for acceptance and recognition that could be gained only by drawing closer to the style of those who had already been accepted and recognized, members of the ruling nations and classes.

Change does not occur only in art, but also at the semantic level. Was this tendency imposed by the authorities in an attempt of assimilation or was it due to the desire of the painters to be considered as the official court painters, or at least as the official painters of the Metropolitanate of Karlowitz? Due to the variety of signatures, we can conclude that these changes emerged from the desire of the painters to improve their social status and to their need for recognition. During this period, the painter is no longer a craftsman. $\mathrm{He}$ becomes an artist, his condition is improved as is his social status.

To conclude, the eclectic art developed in Transylvania during this period seems to have been the most appropriate form of expression of the essence of their belief for both the painters and the Orthodox and Greek Catholic communities in Transylvania in their aspiration to gain social recognition and better social status.

${ }^{54}$ Panait, “Tipuri sociale," 56. 